earth's surface, and presumably at great elevations also, supports the generally-received conclusion that the pressure variation is an effect of the annual inequality of temperature.

Having thus good primâ facie evidence for believing that by far the greater part of the annual variation of pressure may be explained on simple hydrostatic principles, I thought it desirable to test this conclusion by Mr. Archibald's method of substraction, making use of somewhat fuller data than were at his disposal when he wrote the letter above referred to. The observations I have adopted are those of Roorkee, 887 feet above the sealevel; Dehra, 2,232 feet; Chakráta, 7,052 feet, and Leh, 11,503 feet elevation. The first three stations lie within a few miles of each other, their latitudes being $29^{\circ} 52^{\prime}, 30^{\circ} 20^{\prime}$ and $30^{\circ} 40^{\prime} \mathrm{N}$. respectively. Leh is at a considerable distance to the north, in latitude $34^{\circ} 10^{\prime} \mathrm{N}$. The four stations are situated nearly on the same meridian, the difference of longitude between the most westerly and the most easterly amounting to less than half a deuree.

The mean annual values of temperature and pressure at these four places are the following :-
Station.

Roorkee

Dehra

Leh

(17 years)
(12 $"$,
(10-1 I ",
(2-7")

Chakráta
Temperature.

$74^{\circ} 9^{\circ} \mathrm{F}$. $70^{\circ} 6^{\circ} \mathrm{F}$ $56^{\circ} 3^{\circ} \mathrm{F}$ $39^{\circ} 3^{\circ} \mathrm{F}$.
Pressure. (12 years) 28.889 inches. (12,") 27.567 (4,") 23.225, $(4-6, ")$ ) 19.659,
With the exception of the temperature figures for the winter months at Leh, the data are all for sufficiently long periods to be taken as fairly representing normal values of temperature and pressure. From these the average temperatures and barometric weights of three successive strata of air have been calculated, and the results, together with the variations in each month from the annual average values, are given in the next table.

\begin{tabular}{|c|c|c|c|c|c|c|c|c|}
\hline $\begin{array}{c}\text { Strata be- } \\
\text { tween }\end{array}$ & \multicolumn{2}{|c|}{$\begin{array}{c}\text { Roorkee and } \\
\text { Delura. }\end{array}$} & \multicolumn{2}{|c|}{$\begin{array}{l}\text { Dehra and } \\
\text { Chakráta. }\end{array}$} & \multicolumn{2}{|c|}{$\begin{array}{c}\text { Chakráta and } \\
\text { Leh. }\end{array}$} & \multicolumn{2}{|c|}{$\begin{array}{c}\text { Roorkee and } \\
\text { Leh. }\end{array}$} \\
\hline $\begin{array}{l}\text { Ver } \\
\text { thic? }\end{array}$ & \multicolumn{2}{|c|}{ I, 345 feet. } & \multicolumn{2}{|c|}{ 4,820 Feet. } & \multicolumn{2}{|c|}{4.45 I Feet. } & \multicolumn{2}{|c|}{ ro,6 66 Feet. } \\
\hline \multirow{2}{*}{$\begin{array}{l}\text { Annual } \\
\text { means. }\end{array}$} & Tem. & $\begin{array}{c}\text { Bar. } \\
\text { Weight }\end{array}$ & Tem. & $\begin{array}{c}\text { Bar. } \\
\text { Weight }\end{array}$ & Tem. & $\begin{array}{c}\text { Bar. } \\
\text { Weight }\end{array}$ & Tem. & $\begin{array}{l}\text { Bar. } \\
\text { Weight }\end{array}$ \\
\hline & $7^{2} \cdot 8^{0}$ & $I^{\prime} 3^{22^{\prime \prime}}$ & $63^{\circ} 4^{\circ}$ & $4342^{\prime \prime}$ & 47.80 & $3^{\prime} 5^{66^{\prime \prime}}$ & $57 \cdot 1^{0}$ & $9.230^{\prime \prime}$ \\
\hline$\left\{\begin{array}{l}\text { January } \\
\text { February } \\
\text { March } \\
\text { April } \\
\text { May } \\
\text { June } \\
\text { July } \\
\text { August } \\
\text { September } \\
\text { Uctober } \\
\text { November } \\
\text { December }\end{array}\right.$ & $\begin{array}{l}-170 \\
-132 \\
-46 \\
+60 \\
+12.3 \\
+145 \\
+9.5 \\
+8.7 \\
+7.2 \\
+0.8 \\
-9.1 \\
-16.0\end{array}$ & $\begin{array}{l}+.067 \\
+044 \\
+013 \\
-018 \\
-041 \\
-050 \\
-040 \\
-031 \\
-021 \\
-001 \\
+027 \\
+049\end{array}$ & $\begin{array}{l}-15 \cdot 2 \\
-12.6 \\
-5.3 \\
+3 \cdot 3 \\
+70.0 \\
+13.0 \\
+8.9 \\
+8 \cdot x \\
+67 \\
+0.6 \\
-6.1 \\
-12.1\end{array}$ & $\begin{array}{l}+129 \\
+.123 \\
+.050 \\
-022 \\
-.073 \\
-138 \\
-108 \\
-.097 \\
-075 \\
+.003 \\
+.085 \\
+.125\end{array}$ & $\begin{array}{r}-17.2 \\
-149 \\
-7.5 \\
+2.1 \\
+7.5 \\
+13.0 \\
+147 \\
+13.0 \\
+8.6 \\
0.0 \\
-6.4 \\
-12.4\end{array}$ & $\begin{array}{l}+.092 \\
+082 \\
+034 \\
+.017 \\
-040 \\
-074 \\
-070 \\
-048 \\
-031 \\
+004 \\
+.005 \\
+.027\end{array}$ & $\begin{array}{l}-20^{\circ} 0 \\
-155 \\
-6 \% 7 \\
+3 \% 7 \\
+10^{\circ} 2 \\
+150 \\
+157 \\
+13^{\circ} 7 \\
+9^{\circ} 2 \\
+0^{\circ} 1 \\
-9.3 \\
-16^{\circ} 6\end{array}$ & $\begin{array}{l}+289 \\
+.249 \\
+.097 \\
-022 \\
-152 \\
-.262 \\
-217 \\
-176 \\
-126 \\
+.007 \\
+117 \\
+201\end{array}$ \\
\hline
\end{tabular}

From these figures it is evident that when the temperature is above the average the pressure is below it, and vice versa. The only exceptions to this rule, which applies to each separate stratum of air as well as to the whole thickness of 11,616 feet, occur in the months of April and October, when the variations of the barometric pressure from the mean of the year are within the limit: of the probable error of the observations.

The variations of the density of each layer of the atmosphere are also very nearly proportional to the temperature variations, as they would be if the air expanded and contracted freely with changes of temperature. Thus the mean decrease of density for one degree of rise in temperature between Roorkee and Chakrata is "00235. At the mean temperature of these two stations, $65^{\circ} 6^{\circ}$, the co-efficient of expansion per degree Fahr. is 0019 . The observed variation of density is thus slightly greater than that which would be caused by change of temperature alone, but the difference may be completely accounted for by the larger proportion of aqueous vapour in the air in the hot than in the cold months.

Taking the mean pressure of the lowest stratum of air (that between Roorkee and Dehra) to be the arithmetical mean of the pressures ob erved at the top and bottom, and supposing the mean tension of vapour in it to be similarly obtained, we may calculate the ratio of its densities in the hottest and coldest months by the usual formula :-

$$
\frac{d^{\prime}}{d^{\prime}}=\frac{\mathrm{P}-\frac{8}{8} f}{\mathrm{P}^{\prime}-\frac{3}{8} f^{\prime}} \quad \frac{460+t}{460+t}
$$

With the data $\mathrm{P}=28^{\circ} 428, \mathrm{P}^{\prime}=27^{\circ} 982, f=\cdot 30 \mathrm{r}, f_{2}=\cdot 695$, and the temperatures given in the preceding table, the ratio of the density in June to that in January comes out ${ }^{\circ} 92 \mathrm{r}$, while the ratio of the barometric weights is $9 \mathrm{r} 6$. A similar calculation for the stratum between Dehra and Chakrata gives the ratio of the densities in the hottest and coldest months equal to 933 , that of the barometric weights being 943 .

It follows from these results that the annual variation of the barometer over the plains of India and up to a considerable elevation in the Himalayas may be explained by simple hydrostatic principles. A moment's consideration will also show that the double oscillation observed at the hill stations, which is somewhat puzzling at first sight, may be explained in the same way, without bringing in any hypothetical saturated antimonsoon current.

It is the combination of this, at frst sight, anomalous variation in the upper regions of the atmosphere, with the variations due to simple changes of density below, that gives rise to those peculiarities of the annual change of pressure in India which led Mr. Brown to give the weight of his great name in meteorology to an opinion that is clearly erroneous.

Allahabad, 18th February

S. A. HILL

\section{Gunnery Experiments}

I Have read with interest the leading article on Gunnery Experiments in Nature, vol. xxi. p. 437. The question seems to me to be one not alone of build, but-and perhaps principally -of muzzle-loading versus breech-loading, and of rifling for or without studs. The Admiralty seem to think so, as appears, I presume, from their resolution to adopt breech-loading for the turrets of the Colossus. With breech-loading donble loading is an impossibility, as well as jamming of studs, since there are none, at least in the first artilleries of Europe. I dare say Sir W. Palisser's build is better than any other known in England; but then with it the best guns would be breech-loaders.

Contrary to the grand practice of Europe, England has hitherto, with characteristic tenacity, retained muzzle-loading for great guns. Now she will, I apprehend, have to reform and to pay enormous sums as a penalty, besides enduring the very inconvenient feeling of temporary inferiority in a means of great importance.

The Hague, March I5

\section{A Museum Conference}

I DEPRECATE as strongly, though not so violently, as "Aca. demicus," an association to talk about museums, but I cannot agree with his reasoning on the subject of museums and their curators. I have had twenty years' daily experience of museum work, and at the risk of being dubbed a pretentious curator I can assert $I$ have brought an average intelligence to bear on my work. With a certain amount of sympathy for the strictures of "Academicus" on the multiplication of conferences, I am yet free to assert that in no department of public work might and could greater public advantage result from close association of officials than from a union of museum curators. A provincial curator must often be oppressed with the conviction that he is spending weeks over a task which is already, in some other locality, done to his hands, and he must likewise know that the labour he is in other instances performing, and the objects he is manipulating would be sufficient for the wants of a dozen institutions like his own. He knows that he wants what others have, and that from his abundance others might be filled. Then again, in a general museum, the presiding officer, to be thoroughly efficient, should be master of the circle of the sciences, and have a familiar acquaintance with all arts and art. But science is all-embracing, art is long, and the arts of to-day are obsolete to-morrow. I say in contradiction of "Academicus" that museum officials only know their business when they know their ignorance, and that proper salaries are not their only or chief want. In a scientific sense the best men would be the worst museum curators, and were the municipalities of Great Britain each to offer the salary of a cabinet minister for the services of a museum superintendent, I do not think the institutions would thereby at once be so much revolutionised as "Academicus" thinks. 